Cascavel, 07 de julho de 2017.

\title{
Declaração de revisão de texto
}

Declaro, para os devidos fins, que realizei a revisão do artigo "Mídia e ascensão conservadora" de autoria de Carla Luciana Silva.

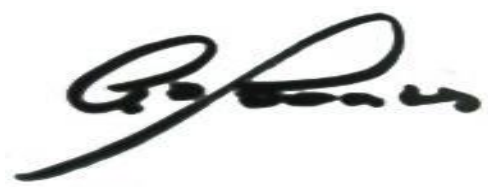

Dr. Alexandre Sebastião Ferrari Soares 